\title{
Locally Advanced Unresectable Malignant Neoplasm
}

National Cancer Institute

\section{Source}

National Cancer Institute. Locally Advanced Unresectable Malignant Neoplasm. NCI

Thesaurus. Code C153278.

A malignant neoplasm that has spread from its original site of growth to nearby tissues

or lymph nodes and is not amenable to surgical resection. 